\title{
Analysis of the co-movements in the short term of commodities oil, mineral coal and crude oil
}

\author{
Claudia Aline de Souza Ramser', Adriano Mendonça Souza"
}

\begin{abstract}
The main purpose of this study is to determine the relationship among oil, crude oil and mineral coal commodities, from 1997 to 2015 to understand, identify, and quantify their impact on short-term relationship using the autoregressive vector models. The methodology of autoregressive vectors will provide the assessment of impulse-response functions and variance decomposition applied to commodities included in this study. Our findings show that oil affects mineral coal and crude oil prices, and its own price; but it is not affected by order variables. Oil causes an unstable behavior on the other variables, presenting positive and negative effects, all variables, after suffering external shocks, have returned to their normal oscillation levels up to the 7th period. An impulse of one standard deviation in crude oil affect mineral coal positively and negatively, and begin to get stable at 9th period. The response to crude oil is oscillatory when mineral coal receive an external shock, and begin to stabilize at 6th month. The knowledge of their behavior over time is important to managers do assertive decisions with adequate strategic planning based on the scientific informations.
\end{abstract}

Keywords: Mineral Commodities. Autorregressive Vectors. Response Impulse 


\section{INTRODUCTION}

The Brazilian mineral industry was boosted by the developed countries, which were responsible for increased in ore imports. According to the Ministry of Mines and Energy (2016), Brazil's exports totaled US $\$ 191.1$ billion in 2015, a drop of 14.1\% over the previous year. The countries to which Brazil most exported in the year 2015 were China, United States, Argentina, the Netherlands and Japan, the main products exported are iron ore, iron, steel, crude oil, soy and derivatives, automobiles, Cane sugar, airplanes, beef, coffee and chicken (BNDES, 2016).

Analyzing the current transformations and challenges facing the Brazilian economy, economists such as Alberto Ramos (analyst at Goldman Sachs), Maurício Molan (Santander's chief economist), among others, point to the end of the supercycle of the increase in consumption of mineral commodities, (CANUTO, 2014).

The global deceleration caused by the international financial crisis forces the fall in raw material prices and modifies the growth trend that began in 2000. This resulted in a change in the behavior of the Brazilian trade balance (SEABRA et al., 2015).

The commodities used in this study are: mineral coal, crude oil and oil. According to Borba, $(2015, \mathrm{p} .1)$, it is a solid fossil fuel and, according to Nascimento et al., (2002), is the largest source of non-renewable energy in the country, and the largest reserves are located in Rio Grande do Sul, Santa Catarina and Paraná. Crude oil is extracted through oil refining, and has a great commercial interest (FORTUNY et al., 2008).

Oil is a raw material used in more than 350 products and gives rise to various derivatives used in industry. Although mineral coal and oil and its derivatives come from a non-renewable mineral source, and cause aggression to the environment, these sources of energy are still widely used by rich and emerging countries and, therefore, it is a very representative variable to the World economy (SILVA et al., 2005).

This study is important to understand the interrelationship among the variables and verify is the price of one is capable to interfere in the price of others. And is 
important to show how the variation in one variable affect the level or others. Is the vector autoregressive model able to capture the interrelationship and the impact in level of the variables under study.

This research aimed to understand the co-movements of commodities oil, crude oil and mineral coal, in the short-term relationship through autoregressive vectors and the impulse response methodology.

The knowledge of their behavior over time is important to managers do assertive decisions with adequate strategic planning based on the information of the analyzes performed, making the enterprises more competitive.

\section{AUTORREGRESSIVE VECTOR - VAR}

The autoregressive vector (VAR) models (CHAREMZA e DEADMAN,1997) are more commonly used in economic variables when we want to study the behavior of different regions, sectors or countries, considering the same variables as definitions (HILL e LEAVER, 1999). In this way, the VAR model is used, which allows analyzing the interrelationship among the series under study. The participation of each variable in the explanation in the model is performed through variance decomposition, and also allows determining the impact on the endogenous variable when an external shock or innovation occurs, being evaluated by means of the impulse-response technique (SENNA e SOUZA, 2016).

The VAR models allow us to analyze the interrelationships among the multiple variables from minimum constraints, which are the stationarity of the series and the number of lags to be included in the model, thus maintaining the same lag structure, called structural VAR $(p)$ with lagged variables (ENDERS,1995), (BENTES, 2015) (TSAI, 2017) represented in equation 1.

$$
\delta+\boldsymbol{\Theta}_{1} \gamma_{t-1}+\cdots \boldsymbol{\Theta}_{p} \gamma_{t-p}+\varepsilon_{t}
$$

Where: $\delta$ it is the constant, $\Theta(\mathrm{j}=1,2, \ldots, p)$ is an array of parameters $k x k$; Is a $k$-dimensional vector of white noise terms. 
The orthogonalization is performed by decomposition of the covariance matrix known as Cholesky decomposition, which makes lower triangular matrix of errors (CAVALCANTI, 2010).

The variance decomposition describes the movements when a shock is applied to the variable itself and when it is applied to the other variables (ANDINI, 2006). If the error of one variable explains nothing of the variance of the error in the other variable, it is said to be exogenous, and it evolves independently of shocks in the errors in the endogenous variables (MAYORGA et al., 2007). The variance decomposition calculates the percentage of the prediction error variance, which is derived from each endogenous variable, throughout the forecast (BUENO,2008).

The steps for estimating a VAR model are described in the methodology, as well as the tests necessary for its estimation.

\section{METHODOLOGY}

Mineral commodities included in this research are mineral coal, oil and crude oil to the size from 1997 to 2016, totaling 19 years corresponding to 216 monthly observations for each variable. These data were collected from the Foreign Trade Information Analysis System, called AliceWeb, available at http://aliceweb.mdic.gov.br, from the Foreign Trade Secretariat, from the Ministry of Development, Industry and Foreign Trade (MDIC), these data are public.

To fit the VAR model a graphical analysis to each variable is done to understand the behavior of the series in relation to its stationarity. The unit roots Dickey-Fuller (DICKEY e FULLER, 1979) and Kwiatkowski, Phillips, Schmidt and Shin (KPSS) (KWIATKOWSKI et al., 1992), tests are done, to classify the series in I(0) or I(d) Bueno (2011). The VAR model imposes the stationarity constraint, ie, I (0). If the series are classified as non-stationary, "d" differences will be necessary to turn on stationary (BENTES, 2015).

Initially, a VAR model with stationary series is fitted using an arbitrary number of lags to series, with different lags lengths to each model the criteria Akaike 
Information Criterion (AIC) and Bayesian Information Criterion (BIC) are calculated Maddala(1992), according to equations 2 and 3:

$$
\begin{aligned}
& A I C_{p}=-2 \log \left(L_{p}\right)+2[(p+1)+1] \\
& B I C_{p}=-2 \log \left(L_{p}\right)+[(p+1)+1] \log (n)
\end{aligned}
$$

The lowest values for AIC and BIC determine the number of $p$ lags to be used in the model VAR ( $p)$, this procedure is referred to as the lag order criteria.

After to accomplish this step, is important to determine the order to include variables in the model by means of block exogeneity test conducted by the Wald test, and the VAR model is fit again with correct number of lag in the lagged variables and the order that each variable enter in the model, details at Charemza e Deadman, (1997). The most exogenous variable is the first to enter in the model. The variables ordering is important to reflected the quality of the estimated values in the impulse response and the variance decomposition when performed (BOUTABBA,2014).

Defined, adjusted and validated the model, which must present residues with white noise characteristics and non-autocorrelated, it is possible to carry out an Impulse-Response function Charemza e Deadman, (1997), the decomposition of variance Bueno (2008).

To make an impulse response the Cholesky (CAVALCANTI, 2010) decomposition is used, so one impulse and/or impact is imputed in the innovation of the equation selected to be analyzed, the impulse used in this study is of 2 standard deviation. The impact imputed in the innovation is transmitted for all variables presented in the equation, enabling to follow the behavior in the short term. This analysis makes it possible to evaluate the impacts on mineral price commodities under study, from shocks performed in the most relevant commodity.

The variance decomposition is useful to see how much each variable contribute to explain the variable under study, so it is possible see how much mineral price commodities compose the price of each variable in the short term.

Following these steps, it is sought to verify the relationships of oil, crude oil and mineral coal in a short-term horizon. 


\section{RESULTS}

Regarding initially the commodities: mineral coal, oil and crude oil; According to Figure 1, it is observed that the series show a non-stationary behavior, since they do not oscillate around a constant value.

Figure 1 - Mineral Prices commodities figure 1 (a) oil, figure 1 (b) crude oil and figure $1(C)$ mineral coal, level

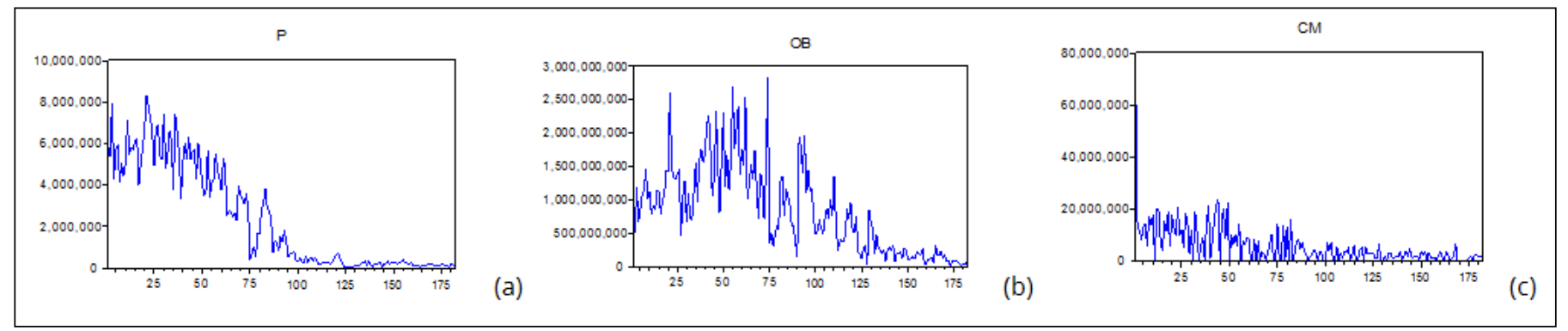

Source: authors

In order to make the series stationary, differences are applied to reach the necessary assumption of stationarity and to adjust the VAR model, the series in first differences are presented in Figure 2.

Figure 2 - Mineral Prices commodities figure 2 (a) oil, figure 2 (b) crude oil and figure $2(\mathrm{C})$ mineral coal, in first differences

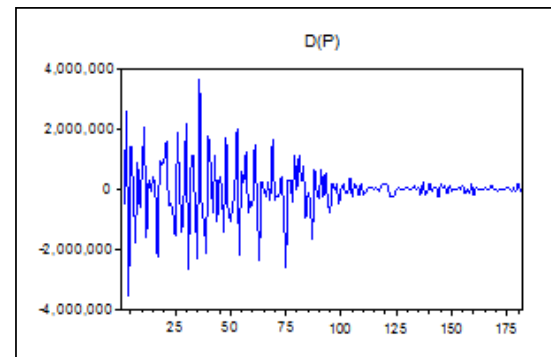

(a)
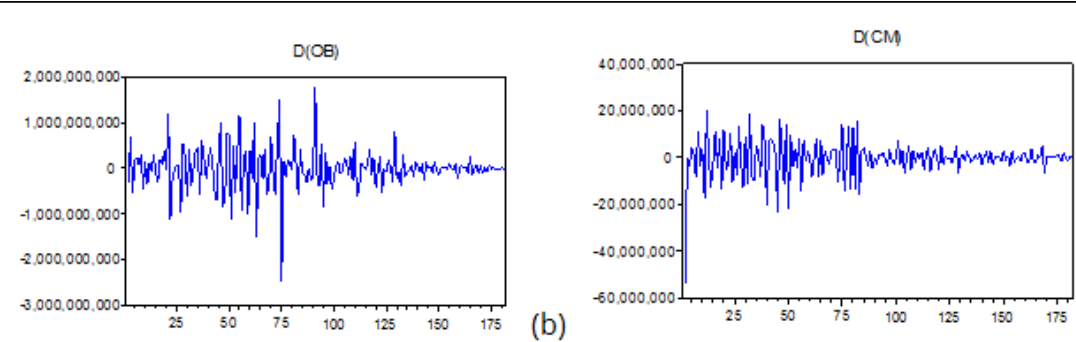

(c)

Source: authors

In Figure 2, to confirm that the series have become stationary, after the difference, the ADF and KPSS tests Table 1 were used. 
Table 1 - Augmented Dickey-Fuller (ADF) and Kwaiatkowski, Pillips, Schmidt and Shein (KPSS) unit root test for variables in level and first differences

\begin{tabular}{lcccccc}
\hline \multirow{2}{*}{ ADF } & \multicolumn{3}{c}{ Level } & \multicolumn{3}{c}{ 1st difference } \\
\cline { 2 - 7 } & OB & P & CM & OB & P & CM \\
\hline Statistics-t & $-2,34$ & $-1,77$ & $-2,30$ & $-16,06$ & $-15,38$ & $-15,32$ \\
Critical value of the ADF 5\% & $-2,87$ & $-2,87$ & $-2,87$ & $-2,87$ & $-2,87$ & $-2,87$ \\
P-value & 0,157 & 0,393 & 0,173 & 0,00 & 0,00 & 0,00 \\
\hline \multirow{2}{*}{ KPSS } & \multicolumn{3}{c}{ Level } & \multicolumn{4}{c}{1 st difference } \\
\cline { 2 - 8 } & OB & $P$ & CM & OB & P & CM \\
\hline LM -stat & 1,35 & 1,59 & 1,62 & 0,11 & 0,12 & 0,31 \\
Critical value of KPSS 5\% & 0,46 & 0,46 & 0,46 & 0,46 & 0,46 & 0,46 \\
\hline
\end{tabular}

MacKinnon (1996) one-sided p-values, (OB: crude oil, CM: mineral coal, P: Oil)

Kwiatkowski-Phillips-Schmidt-Shin (1992, Table 1).

In Table 1, we do not reject the null hypothesis that series in level have unit roots, so the series are considered I (1), but in first differences the null hypothesis is rejected and all series are considered stationary - I (0).

To confirm the decision of the ADF test, we use the KPSS test (MASAYOSHI HAYASHI, 2014), where the null hypothesis of stationarity is rejected, considering the series level, so all are considered I (1). After application of the tests in the series in differences, they become stationary - I (0). To determine the number of lags, sets a general VAR model, a range of up to 8 lags and it is estimated that to point a lower value for the AIC and BIC statistics should be used.

Table 2 - Lag Length Criteria for selecting the order of the VAR (p)

\begin{tabular}{lll}
\hline Lag & AIC & BIC \\
\hline 0 & 107.2902 & 107.3449 \\
1 & 106.6146 & 106.8333 \\
2 & 106.1780 & 106.5607 \\
3 & 106.0323 & 106.5792 \\
4 & 105.8960 & 106.6069 \\
5 & 105.9091 & 106.7840 \\
6 & 105.8588 & 106.8977 \\
7 & 105.7966 & 106.9996 \\
8 & 105.7990 & 107.1660 \\
\hline \multicolumn{2}{l}{ Akaike Information Criterion (AIC) and Bayesian Information Criterion (BIC) }
\end{tabular}

According to Table 2, the highlights indicate the best values found, the lowest AIC=105.7666 estimated model with a lag of 7, i.e., VAR (7) and BIC=106.5607 model with a lag 2, I.e., VAR (2). The BIC criterion is more consistent for large samples and generally provides the choice of a more parsimonious model that AIC (SOBRAL e BARRETO, 2011). The order of the variables that will make the model was determined 
by the Block Exogenety Wald test, which were disposed of more exogenous to the most endogenous Nguyen (2011), in the following order: mineral coal, crude oils and oil. This ordination is important, because at the moment of performing the impulse of response there will be the influence of this ordering. The Granger causality test, according to Table 3, was used to test the causal relationship of variables two to two.

Table 3 - Granger causality test applied in the variables oil (P), mineral coal (CM), crude oil (OB)

\begin{tabular}{lccc}
\hline Null Hypothesis: & Obs & F-Statistic & $p$-value. \\
\hline D(OB) does not Granger Cause D(CM) & 179 & 3.03598 & 0.0506 \\
D(CM) does not Granger Cause D(OB) & & 1.67654 & 0.1900 \\
D(P) does not Granger Cause D(CM) & 179 & 3.57378 & 0.0301 \\
D(CM) does not Granger Cause D(P) & & 3.17721 & 0.0441 \\
D(P) does not Granger Cause D(OB) & \multirow{2}{*}{179} & 3.32405 & 0.0383 \\
D(OB) does not Granger Cause D(P) & & 0.16608 & 0.8471 \\
\hline
\end{tabular}

Based on Table 3, it can be observed that oil and mineral coal are bidirectional, and oil cause crude oil, it can be seen when p-value is less than 0,05. To fit the VAR model is necessary to order the variables from exogenous to endogenous influence, in the following order: mineral coal and crude oil, expressed in oil according Table 4.

Table 4 - VAR model represented in order of exogenous to endogenous

\begin{tabular}{ccc}
\hline Variables & \multicolumn{2}{c}{ Endogenous Variables } \\
\cline { 2 - 3 } & $\Delta(\mathrm{CM})$ & $\Delta(\mathrm{OB})$ \\
\hline$\Delta \mathrm{CM}_{\mathrm{t}-1}$ & -0.734399 & -9.455363 \\
& $(0.06814)$ & $(5.23947)$ \\
& {$[-10.7780]$} & {$[-1.80464]$} \\
$\Delta \mathrm{CM}_{\mathrm{t}-2}$ & -0.226976 & -8.065841 \\
& $(0.06082)$ & $(4.67708)$ \\
& {$[-3.73163]$} & {$[-1.72455]$} \\
$\Delta \mathrm{OB}_{\mathrm{t}-1}$ & 0.001545 & -0.546328 \\
& $(0.00093)$ & $(0.07160)$ \\
& {$[1.65910]$} & {$[-7.62990]$} \\
$\Delta \mathrm{OB}_{\mathrm{t}-2}$ & 0.002175 & -0.355978 \\
& $(0.00092)$ & $(0.07056)$ \\
& {$[2.37051]$} & {$[-5.04490]$} \\
$\Delta \mathrm{P}$ & & \\
& -0.560475 & 42.47584 \\
& $(0.46730)$ & $(35.9328)$ \\
& {$[-1.19939]$} & {$[1.18209]$}
\end{tabular}

Akaike information criterion 76.34811/ Schwarz criterion 76.52618 
In Table 4, the VAR (2) is presented, under each parameter estimated in parentheses are shown the standard error, and the values in brackets are the tcalc statistic. All equations show residue with white noise characteristics, and the adjustments statistics are $\mathrm{AIC}=76.34811$ and $\mathrm{BIC}=76.52618$. It is observed that the $\Delta$ (CM) equation depends on the mineral coal up two lags, and crude oil up to two lags on it in a delay and two delays by it, and by coal. The variable $\Delta(\mathrm{P})$ enters as an instrumental variable in the estimation of the model. The same structure is followed by crude oil. In VAR modeling it is not necessary that variables and lags be significant in all equations, there is a need to establish a statistically significant interrelationship among the equations, through the variables included in them. For the purpose is to understand the co-movements of the system of equations in moments of contemporary times and not the prediction of the variables involved.

A change in one variable affects the other variables, this effect of the external shock is transmitted by the structure of the adjusted VAR for the other variables and the important thing is to observe how many instants of time are necessary for this variable to become stable in front of the shock received. The impulse response is nothing more than the transmission of a signal through the innovations of the adjusted equations. The commodity price of oil is exogenous therefore must be considered an instrumental variable. The endogenous variables mineral coal and crude oil should receive an external shock in terms of standard deviation to analyze the behavior in a short term, as shown in Figure 3.

Figure 3 - Impulse response given to the figure 3 (a) mineral coal variable and figure 3 (b) crude oil

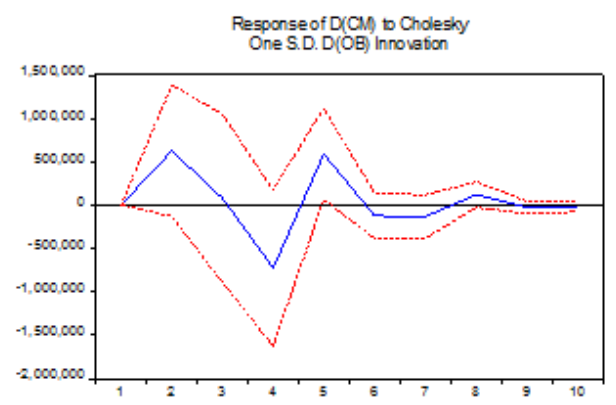

(a)

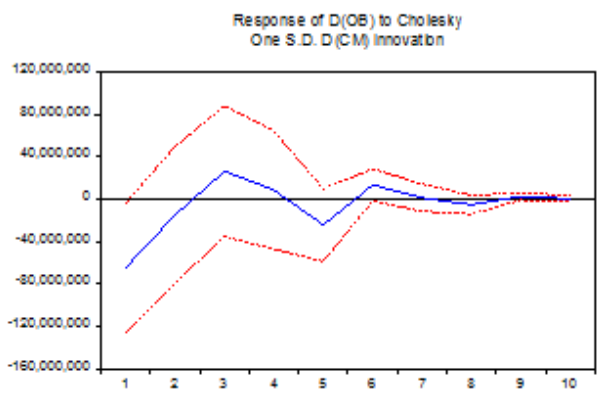

(b) 
In crude oil price (figure 3a), affected by mineral coal price shocks, there is an increase in mineral coal price, with a rise in the second month, contracting in the fourth and fifth months, rising again and adjusting to the level of long-term equilibrium.

In relation to crude oil (figure $3 b$ ) shocks cause this variable to fall in price, increasing again from the fourth to the fifth month, stabilizing in the seventh month.

When performing the variance decomposition, the variance of the forecast error of 10 months ahead was used. The first variable decomposed in Table 5, was the oil, it was analyzed how much, of the same variable, is explained by it and the other variables.

Table 5 - Decomposition of Variance oil, mineral coal price and crude oil

\begin{tabular}{|c|c|c|c|c|}
\hline \multicolumn{5}{|c|}{ Decomposition of Variance $D(P)$} \\
\hline Period & Forecast Error & $\mathrm{D}(\mathrm{P})$ & $\mathrm{D}(\mathrm{CM})$ & $\mathrm{D}(\mathrm{OB})$ \\
\hline 1 & 784260.9 & 100.0000 & 0.000000 & 0.000000 \\
\hline 5 & 887121.7 & 96.58828 & 3.166975 & 0.244745 \\
\hline 10 & 889965.0 & 96.50975 & 3.229071 & 0.261175 \\
\hline \multicolumn{5}{|c|}{ Decomposition of Variance D (CM) } \\
\hline Period & Forecast error & $D(P)$ & $\mathrm{D}(\mathrm{CM})$ & $\mathrm{D}(\mathrm{OB})$ \\
\hline 1 & $5,300,155$ & 1.019026 & 98.98097 & 0.000000 \\
\hline 5 & 7083013. & 4.472786 & 93.67678 & 1.850438 \\
\hline 10 & 7089428. & 4.502874 & 93.52444 & 1.972689 \\
\hline \multicolumn{5}{|c|}{ Decomposition of Variance D (OB) } \\
\hline Period & Forecast Error & $\mathrm{D}(\mathrm{P})$ & $\mathrm{D}(\mathrm{CM})$ & $\mathrm{D}(\mathrm{OB})$ \\
\hline 1 & $4.08 \mathrm{E}+08$ & 3.141445 & 2.659736 & 94.19882 \\
\hline 5 & $4.82 E+08$ & 3.502520 & 2.395012 & 94.10247 \\
\hline 10 & $4.83 E+08$ & 3.773472 & 2.468390 & 93.75814 \\
\hline
\end{tabular}

In the first month, $100 \%$ of the variance of the oil price variable is explained by the itself, already in the fifth period, $96.58 \%$ of the variance of the oil is explained by the variable itself; $3.16 \%$ is explained by mineral coal, and $0.24 \%$ is explained by the value of crude oil. In the tenth moment, $96.50 \%$ of the variance of the oil is explained by the variable itself; $3.22 \%$ is explained by coal, and $0.26 \%$ is explained by the value of crude oil. Note that from the fifth period, the participation of variables becomes stable in relation to the share of coal and crude oil, is small relative to the explanation of the oil price. In the first month, $98.98 \%$ of the variance of the mineral coal variable 
is explained by itself, and $1.01 \%$ is explained by the oil. Already, in the fifth period, $93.67 \%$ of the variance of mineral coal variable is explained by itself; $4.47 \%$ is explained by oil, and $1.85 \%$ is explained by the value of crude oil. In the tenth moment, $93.52 \%$ of the variance of mineral coal is explained by itself; $4.52 \%$ is explained by oil, and $1.97 \%$ is explained by the value of crude oil. It was observed that from the fourth period, the participation of variables becomes stable in relation to the share of oil and crude oil, since it is small in relation to the explanation of the mineral coal price.

Analyzing the crude oil variance, there is stability in the values of the prediction error of the variance, as months pass by. In the first month, $94.19 \%$ of the variance of crude oil is explained by the variable itself, $3.14 \%$ is explained by oil, and $2.65 \%$ is explained by coal. In the fifth period, $94.10 \%$ of the crude oil variance is explained by the variable itself; $3.50 \%$ is explained by oil and $2.39 \%$ is explained by the value of mineral coal. In the tenth moment, $93.75 \%$ of the crude oil variance is explained by the variable itself; $3.77 \%$ is explained by oil, and $2.46 \%$ is explained by the value of mineral coal. These values stabilize from the seventh month.

\section{CONCLUSION}

This study enabled the analysis of the relationship among the prices of the main Brazilian mineral commodities of oil, mineral coal and crude oil, through the VAR model, from 2000 to 2016. According to MDIC data, the variables studied are of great relevance in the country's economic growth, since up to 2015, they were the most exported raw materials in Brazil.

Through the analysis, it was verified that the series have oscillated over the years. Since 2010, the values of mineral commodities have undergone significant growth, with China as the largest Brazilian iron ore buyer. Considering the analyzed commodities, China surpassed the United States and Argentina in the ranking of Brazil's main trading partners. In 2008 there is a loss referred to the fall in demand for minerals in the world, as a result of the explosion of the housing market in the United 
States, but then there is a recovery through the sale of iron with China (MACHADO, 2015).

Among 2002 and 2012, the growth of Brazil's economy depended on exports of minerals and agricultural commodities. But the sharp decline in prices of these commodities in the world market took place from 2013 and jeopardizes this growth. In the year 2007, there is growth, but quickly in 2008, there is a bigger fall than the increase. In this way, peaks above the historical average occur, which falls in 2013. As a result, the market remains below the world average of the last 40 years. In 2015, with the slowdown in China's growth, the mineral prices commodities also experienced a decrease of its market value. Brazil has been suffering great losses with the change in the economic model of this Asian country, the iron price ore reduced by 43\% in recent months, according to the Brazilian Foreign Trade Association in 2016.

The slowing of Chinese growth causes damage in Brazil, causing an economic crisis. Therefore, China has made the commodities price traded on international markets plummeted. This fall in prices generates fluctuations in the Shanghai Stock Exchange, which reaches several markets in the world. This volatility, together with the depreciation of the Japanese currency Yuan, reaches the steel, Brazilian mining and oil and, likewise, Bovespa (CASOTTI et al., 2015), (SILVA, 2014).

There was a drop-in world oil production, with prices not falling, which may occur in periods of strong oil demand, growth in the economy of exporting countries, (LEDER e SHAPIRO, 2008). This occurred in Brazil in the period from 2010 to 2015, however, Brazilian policy has not invested these profits in national consumer goods industries to remain a competitive country. It is known that commodities always go through cycles and during this period generated a surplus, but there are periods of falling prices. Meyer et al., (2009) indicate negative impacts on oil importing countries in their study when using structural econometric models. In this way we can understand the oscillations represented in the graph, because changes occurred in the world economy, reflecting in the price and consumption of the commodities under study. 
In the estimation of the VAR model, oil is the variable that influences the price of other commodities. Thus, this variable could be responsible for the oscillations prices in the analyzed commodities. In order to compose and understand the behavior of the variables under study, we performed the variance decomposition, which resulted that oil price influence crude oil and mineral coal.

With regard to these results also there is a statistically significant interrelationship between the equations, by means of the variables included in the model in them, which could be evaluated by means of impulse-response functions. They indicated that endogenous shocks exert an oscillatory behavior on the other variables of the model, presenting positive and negative effects over time.

According to the impulse-response function, an increase or fall in the price of the endogenous variables, will have reflexes in value of these commodities, and are perceived in all series of the model. This behavior in the short term also results in changes, because when there is a change in the variable price, this oscillation affects the other variables. But the shocks are transient, and the variables enter into equilibrium in the long term. However, analysis of variance decomposition of the forecast error indicated a growing share of mineral commodities from the second period, over time analysis.

The research limitations arise on the sample size of the variables and the number of commodities under study. The suggestion for future studies, is analyze other commodities traded in the Brazilian trade balance, such as: agricultural, financial and environmental, and also examine the volatility of these commodities. 


\section{REFERENCES}

AKRAM, QF. [Commodity prices, interest rates and the dollar. Energy economics]. 2009;31(6): 838-851. English

BENTES, SR. [On the integration of financial markets: How strong is the evidence from five international stock markets?] Phys. A Stat. Mech. its Appl. 2015;429: 205-214. English

BNDES. Perspectivas do Investimento 2015 - 2018 e Panoramas Setoriais. Boletim elaborado pela Área de Pesquisa e Acompanhamento Econômico (APE) e pelo Comitê de Análise Setorial (CAS). Biblioteca Digital. [Internet]. 2014; [cited 2016 Mar 09]. Available from: https://web.bndes.gov.br/bib/jspui/bitstream/1408/7361/1/boletim_perspectivas_feve reiro2016_P_BD.pdf

BORBA, RF. Carvão Mineral. Fontes Energ. [Internet]. 2015;1: 1-19. [cited 2016 Abr. 19]. Available from: http://www.mundoeducacao.com/geografia/carvao-mineral.htm

BOUTABBA, MA. [The impact of financial development, income, energy and trade on carbon emissions: Evidence from the Indian economy]. Econ. Model. 2014;40: 33-41. English

BUENO, RLS. Econometria de Séries Temporais, $2^{\circ}$ ed. Cengage Learning. 2011; São Paulo.

BUENO, RLS. Econometria de Séries Temporais. Cengage Learning. 2008; São Paulo.

ANDINI, C. [Unemployment and Welfare Participation in a Structural VAR: Rethinking the 1990s in the United States]. International Review of Applied Economics. 2006;20(2): 243-253. English

CANUTO, O. [The Commodity Super Cycle: Is This Time Different?] Economic Premise. 2014;150: 1-4. English

CASOTTI, BP.; FILHO, EDB; CASTRO, PC. de. China desacelera e põe fim à bonança das commodities. [Internet]. 2015;121-162. [cited 2016 Out.. 09]. Available from: http://infograficos.estadao.com.br/economia/por-que-o-brasilparou/commodities.php.

CAVALCANTI, MAFH. Identificação de modelos VAR e causalidade de Granger: uma nota de advertência. Econ. Apl. 2010;251-260. 
CHAREMZA, W., DEADMAN, D. New Directions in Econometric Practice General to specific Modelling, Cointegration and Vector Autoregression, $2^{\text {a }}$ ed. Edward Elgar Pub. 1997; pg.1 -370.

DICKEY, DA.; FULLER, WA. [Distribution of the Estimators for Autoregressive Time Series With a Unit Root]. J. Am. Stat. Assoc. 1979;74: 427-431. English

ENDERS, W. Applied econometric time series.Wiley series in probability and mathematical statistics, in: John Wiley and Sons. New York /USA. 1995.

FORTUNY, M.; et al. Principais aplicações das microondas na produção e refino de petróleo. Quim. Nova. 2008;31: 1553-1561.

FRIZO, P.; LIMA, R.A. de S. Efeitos da flutuação dos preços das commodities no fluxo de investimento estrangeiro direto no Brasil. Rev. Econ. Contemp. 2014;18: 393-408.

HILL, J.; LEAVER, JD. [Effect of stage of growth at harvest and level of urea application on chemical changes during storage of whole-crop wheat]. Anim. Feed Sci. Technol. 1999;77: 281-301. English

KILIAN, L. [Exogenous Oil Supply Shocks: How Big Are They and How Much Do They Matter for the U.S. Economy?]. Rev. Econ. Stat. 2006;90: 216-240. English

KWIATKOWSKI, D.; PHILLIPS, PCB., Schmidt, P., Shin, Y. [Testing the null hypothesis of stationarity against the alternative of a unit root]. J. Econom. 1992;54: 159-178. English

LEDER, F., SHAPIRO, JN. [This time it's different. An inevitable decline in world petroleum production will keep oil product prices high, causing military conflicts and shifting wealth and power from democracies to authoritarian regimes]. Energy Policy. 2008;36: 2840-2842. English

MACHADO, I. Fim da bolha das commodities minerais obriga Brasil a repensar seu papelnomercadomundial. Longevidade ADunicamp. [Internet]. 2015;[cited 2016 Jan 12]. Available from: http://longevidadeadunicamp.org.br/?p=1415

MADDALA, GS. Introduction to econometric. Cliffs, Englewood; New Jersey; $2^{\circ}$ ed. 1992.

MASAYOSHI H. Previsão de casos de assistência social: o caso do programa de assistência pública japonesa. Ciências do Planejamento Socioeconômico, 2014;48: 2, 105-114.

MAYORGA, RDO. et al. Análise de transmissão de preços do mercado atacadista de melão do Brasil. Rev. Econ. e Sociol. Rural. 2007;45: 675-704. 
MEYER; L., TSATSARONIS, G.; BUCHGEISTER, J.; SCHEBEK, L. [Exergoenvironmental analysis for evaluation of the environmental impact of energy conversion systems]. Energy. 2009;34: 75-89. English

MINISTÉRIO DE MINAS E ENERGIA (MME). Resenha Energética Brasileira. [Internet]. 2016; [cited 2016 Out. 12]. Available from: www.mme.gov.br/documents/10584/3580498/02\%2B\%2BResenha\%2BEnerg\%25C3\%25A9tica\%2BBrasileira\%2B2016\%2B\%2BAno\%2BBase\%2B2015\%2B(PDF).

NASCIMENTO, FMF.; MENDONÇA, RMG.; MACÊDO, MIF.; SOARES, PSM. Impactos ambientais nos recursos hídricos da exploração de carvão em Santa Catarina. Companhia de Pesquisa de Recursos Minerais - CPRM. 2002; pg.1 12.

NGUYEN, HT. [Discussion Papers in Economics]. Work. Pap. 2011;11(03): 1-47. English

SEABRA, F., KOMOTO, NT., SAMPAIO, CV. Atualidade econômica, Boletim Edição Especial sobre Brasil e Crise. [Internet]. 2015;64: 1-33. [cited 2016 Nov. 12]. Available from: http://cnm.ufsc.br/files/2015/11/BOLETIM-N.-64-24-de-novembro.pdf

SENNA, V. de, SOUZA, AM. [Assessment of the relationship of government spending on social assistance programs with Brazilian macroeconomic variables]. Phys. A Stat. Mech. its Appl. 2016;462: 21-30. English

SILVA, CRA. da, GARRAFA, MTF., NAVARENHO, PL., GADO, R., YOSHIMA, S. Energia e Ambiente A Biomassa Como Alternativa Energética Para O Brasil, in: Revista Brasileira de Ciências Ambientais. 2005;25-36.

SILVA, LAP. da. Os novos contornos da economia global no pós-crise e suas implicações para a agenda de crescimento do Brasil, in: Palestra na CCFB-Câmara de Comércio França-Brasil em São Paulo. 2014;1-14.

SOBRAL, TEL., BARRETO, G. Análise dos Critérios De Informação para a seleção de

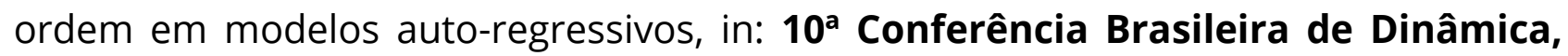
Controle e Aplicações. 2011;379-382.

TSAI, IC. [The source of global stock market risk: A viewpoint of economic policy uncertainty]. Econ. Model. 2017;60, 122-131. English 